\title{
ALTERNATIF PENGGUNAAN SERAT ECENG GONDOK PADA CAMPURAN STONE MATRIX ASPHALT GRADASI HALUS MENINGKATKAN STABILITAS CAMPURAN ASPAL PANAS
}

\author{
Teguh Kurniawan ${ }^{1}$, Zulkifli Lubis ${ }^{2}$ \\ ${ }^{1,2}$ Fakultas Teknik Universitas Islam Lamongan \\ email: teguh kurniawan 09@gmail.com.cheppy.lubis@gmail.com
}

\begin{abstract}
In this mixture using cellulose fibers derived from water hyacinth to find out whether water hyacinth fiber can be used as a mixture of hot asphalt and as a substitute for cellulose fibers in the market. In this study, the laboratory experimental research method is used to conduct experimental activities to produce a result of water hyacinth fiber mixing with Marshall Properties. The purpose of this experiment is to compare the results obtained at optimum levels in the specifications of SNI Specifications for Stone Matrix Asphalt (SMA) 2015, with the addition of water hyacinth fiber variations of $1 \%, 2 \%, 3 \%, 4 \%, 5 \%$ taken from asphalt content. The final result of this study was Marshall evaluation where Stability was $55830.18 \mathrm{~kg}$ on $3 \%$ water hyacinth fiber content, $17.09 \%$ VIM on 5\% water hyacinth fiber content, $172.40 \%$ VMA on 5\% water hyacinth fiber content, VFWA $2100.28 \%$ on $0 \%$ water hyacinth fiber content, $2.23 \mathrm{~mm}$ flow on $4.9 \%$ water hyacinth fiber content, Marshall Quotient $25984.39 \mathrm{~kg} / \mathrm{mm}$ on $3 \%$ water hyacinth fiber content. These results indicate that waterhyacinth fiber cannot be used in a mixture of SNI 2015 Stone Matrix Asphalt Specifications (SMA).
\end{abstract}

Keywords: Water Hyacinth Fiber, Stone Matrix Asphalt, Marshall Properties

\begin{abstract}
Abstrak
Dalam campuran ini menggunakan serat selulosa yang berasal dari eceng gondok untuk mengetahui apakah serat eceng gondok dapat digunakan sebagai campuran aspal panas dan sebagai pengganti serat selulosa di pasaran. Dalam penelitian ini, metode penelitian eksperimental laboratorium digunakan untuk melakukan kegiatan eksperimental untuk menghasilkan hasil pencampuran serat eceng gondok dengan Marshall Properties. Tujuan dari penelitian ini adalah untuk membandingkan hasil yang diperoleh pada tingkat optimal dalam spesifikasi Spesifikasi SNI untuk Aspal Matriks Batu (SMA) 2015, dengan penambahan variasi serat eceng gondok $1 \%, 2 \%, 3 \%, 4 \%, 5 \%$ diambil dari konten aspal. Hasil akhir dari penelitian ini adalah evaluasi Marshall dengan Stabilitas 55830,18 $\mathrm{kg}$ pada 3\% kadar serat eceng gondok, 17,09\% VIM pada 5\% kadar serat eceng gondok, 17,40\% VMA pada 5\% kadar serat eceng gondok, VFWA 2100,28\% pada 0\% kadar serat eceng gondok, aliran 2,23 mm pada 4,9\% kadar serat eceng gondok, Marshall Quotient 25984,39 kg / mm pada 3\% kadar serat eceng gondok. Hasil ini menunjukkan bahwa serat waterhyacinth tidak dapat digunakan dalam campuran Spesifikasi Asphalt Batu Matriks SNI 2015 (SMA).
\end{abstract}

Kata Kunci: Serat Hyacinth Air, Aspal Matriks Batu, Sifat Marshall

\section{PENDAHULUAN}

Konstruksi jalan raya telah mengalami perkembangan yang pesat. Hal ini ditandai dengan semakin lancarnya arus transportasi darat. Kehandalan teknologi dan ilmu pengetahuan sangat diharapkan untuk menghadapi tantangan dalam peningkatan kuantitas dan kualitas jalan yang 
akan dibangun dan dalam masa pemeliharaan. Untuk itu telah lahir suatu teknologi lapis penutup konstruksi jalan yang mempunyai nilai struktural Stone Matrix Asphalt (SMA) merupakan jenis campuran beraspal panas yang dapat digunakan sebagai lapis permukaan dengan berberapa karateristik lapisan yang dapat memberikan keuntungan bagi pengendara karna mempunyai ketahanan gelincir (sekid resistant) yang cukup tinggi. Spesifikasi mencakup persyaratan bahan cukup SMA yang terdiri dari ageregat, bahan pengikat (aspal), serta persyaratan gradasi ageregat campuran dan sifat - sifat campuran. Spesifikasi ini merupakan spesifikasi baru yang berguna sebagai acuan dalam perancangan serta pelaksanaan pekerja campuran SMA untuk pekerja pemeliharaan untuk pembangunan jalan baru, Suaryana, N. (2012). Suaryana, N. (2012). campuran aspal dengan kadar aspal relatif tinggi dibutuhkan untuk memenuhi sifat-sifat di atas agar rongga yang terisi aspal (VFWA) besar sehingga lebih tahan terhadap oksida. Salah satu jenis lapis perkerasan jalan yang menunjang pembangunan diatas yaitu Stone Matrix Asphalt (SMA). SMA tersusun atas Stone Matrix Asphalt (campuran agregat halus, filler dan aspal dengan kadar relative tinggi) ditambah dengan zat additive serat selulosa. Agregat dari SMA mempunyai gradasi terbuka, sehingga dapat memiliki ketebalan lapisan film aspal yang tinggi, hal ini menimbulkan pengaruh positif dan negatif. Pengaruh positifnya adalah karena lapisan dengan ketebalan film aspal yang tinggi akan tahan terhadap sinar ultraviolet dan oksidasi, sehingga akan meningkatkan daya tahan dari lapisan perkerasan jalan, sedangkan pengaruh negatifnya adalah bahwa lapisan aspal ini kurang tahan terhadap temperature tinggi, karena pada kondisi lapisan film aspal yang tinggi ini cenderung terjadi bleeding atau keluarnya aspal ke permukaan, akan tetapi pengaruh negative seperti hal tersebut dapat dikurangi dengan penambahan zat additive berupa serat selulosa yang dapat berfungsi untuk menstabilkan aspal dan meningkatkan viskositasnya,,sebab itu dengan teknologi yang sudah ada akan dilakukan suatu penelitian dengan menambahkan serat selulosa yang di dapatkan dari enceng gondok sebagai bahan campuran pada Laston. Fungsi serat selulosa sebagai bahan campuran aspal ini dapat menyerap aspal, memperkuat kekuatan ashesi dan dapat menstabilkan serta memperkuat aspal. Bahan tambah adiktif sebagai campuran aspal yang di gunakan biasanya serat selulosa. Oleh karena itu perlu dicari alternatif pengganti serat selulosa tersebut. Eceng gondok merupakan suatu gulma air yang sekali tumbuh dan berkembang ternyata mempunyai kandungan serat selulosa cukup tinggi, yakni berkisar $60 \%$. Hal ini sangat memungkinkan bahwa eceng gondok berpotensi sebagai bahan dasar pembuatan selulosa yang kedepannya dapat diaplikasikan ke arah yang beragam. Maka dari itu penelitian ini akan menggunakan eceng gondok sebagai bahan adiktif karena merupakan serat alami yang mudah di temukan dan murah, (R. Davies, 2013). Mengingat di daerah Lamongan banyak dijumpai tanaman eceng gondok yang saat ini masih 
sebagian kecil dimanfaatkan sebagai bahan kerajinan, untuk itu dalam penelitian ini akan mencoba memanfaatkan eceng gondok sebagai bahan campuran (Stone mastic asphalt). Penelitian ini dilakukan untuk mengetahui pengaruh penggunaan serat enceng gondok sebagai bahan pengganti serat selulosa pada campuran Stone mastic asphalt (SMA).

\section{METODE PENELITIAN}

\subsection{Rancangan Penelitian}

Rancangan penelitian atau desain penelitian adalah proses pengumpulan dan analisis data penelitian. Ini berarti bahwa penelitian ini meliputi perencanaan dan melakukan penelitian. Untuk rancangan perencanaan diawali dengan observasi dan evaluasi penelitian yang telah dilakukan dan telah dikenal, sampai pembentukan kerangka diperlukan bukti lebih lanjut. Dalam Implementasi rancangan penelitian termasuk juga membuat eksperimen atau pengamatan, dan juga memilih variabel pengukuran, teknik dan prosedur, pengumpulan data, instrumen, analisis data telah mengumpulkan sampel, dan pelaporan hasil penelitian. Pada pembahasan Karya ilmiah ini penelitian awal menggunakan metode penelitian di laboratorium dengan cara coba-coba/trial and error. Tujuan dari penelitian ini sendiri yaitu untuk mendapatkan hasil dari uji coba pencampuran bahan organik atau gulma berupa Eceng Gondok. Dimana bahan eceng gondok tersebut nantinya akan di campur dengan campuran aspal panas. Sdandar yang digunakan dalam penelitian ini telah diakui dan dipakai di Indonesia.

\subsection{Teknik Pengumpulan Data}

Untuk memperoleh data - data yang diperlukan dalam penelitian, maka dilakukan experimen atau percobaan dilaboratorium. Disamping itu dilakukan pula beberapa wawancara dengan pihak terkait yang berkepentingan.

\subsection{Data Pengujian Bahan Susun Campuran Aspal Panas Stone Matrix Asphalt Gradasi} Halus.

Ageregat cammpuran untuk Stone Matrix Asphalt (SMA) Bahan tambah harus terdiri dari bahan yang telah terbukti baik, dan harus ditambahkan kedalam aspal serta diaduk secara seksama sesuai dengan petunjuk yang diberikan oleh pabriknya sehingga diperoleh campuran yang seragam.

\subsection{Analisis Komparasi Marshall Properties}

Pengujian Marshall Test diperlukan untuk mengetahui kadar aspal optimum yang berasal dari Marshall Properties, disamping itu pengujian ini digunakan pula untuk mengetahui pengaruh penambahan serat selulosa dalam campuran pada kondisi kadar aspal optimum. Oleh karena itulah, pengujian Marshall Test dilakukan bertahap sesuai dengan tujuan penelitian, yakni pertama dilakukan untuk mengetahui kadar aspal optimum dan kedua untuk mengetahui 
pengaruh penambahan serat selulosa dalam campuran terhadap nilai-nilai Marshall Properties yaitu stabilitas Marshall (Marshall Tability), \% Rongga Terisi Aspal (Void Filed With Asphalt / VFWA), \% Rongga Dalam Campuran (Void in The Mix / VIM), Kelelahan Plastis (Flow), Kepadatan Campuran (Density) dan Marshall Quotient (MQ).

\subsection{Analisis Data}

Setelah dilakukan penelitian penambahan serat eceng gondok pada campuran aspal panas, peneliti dapat membandingkan hasil dari test Marshall Properties dengan menggunakan dua jenis benda uji dimana dua benda uji tersebut sebelum diberikan tambahan dan sesudah diberikan tambahan serat eceng gondok. Setelah dilakukan pengujian akan mendapatkan hasil, yang selanjutnya dilakukan dengan membuat pemodelan matematika dengan bantuan software MS Excell 2013 untuk mengetlahui hubungan antara kadar penambahan serat selulosa dengan : (i). kualitas aspal; dan, (ii). nilai-nilai marshall properties.

Hasil akhir merupakan model matematika hubungan pengaruh antara penambahan serat enceng gondok terhadap : (i). kualitas aspal (penetrasi; titik lembek; titik nyala dan titik bakar aspal serta kehilangan berat aspal); dan, (ii). nilai-nilai marshall properties. Hasil analisis data digunakan sebagai dasar untuk menarik kesimpulan.

\section{HASIL DAN PEMBAHASAN}

\subsection{Stabilitas (Stability)}

Stabilitas adalah kemampuan maksimal suatu benda uji campuran beton aspal menahan beban sampai terjadi kelelehan plastis. Nilai stabilitas akan bertambah dengan naiknya kadar aspal sampai ke batas optimum dan akan mengalami penurunan setelah batas optimum.

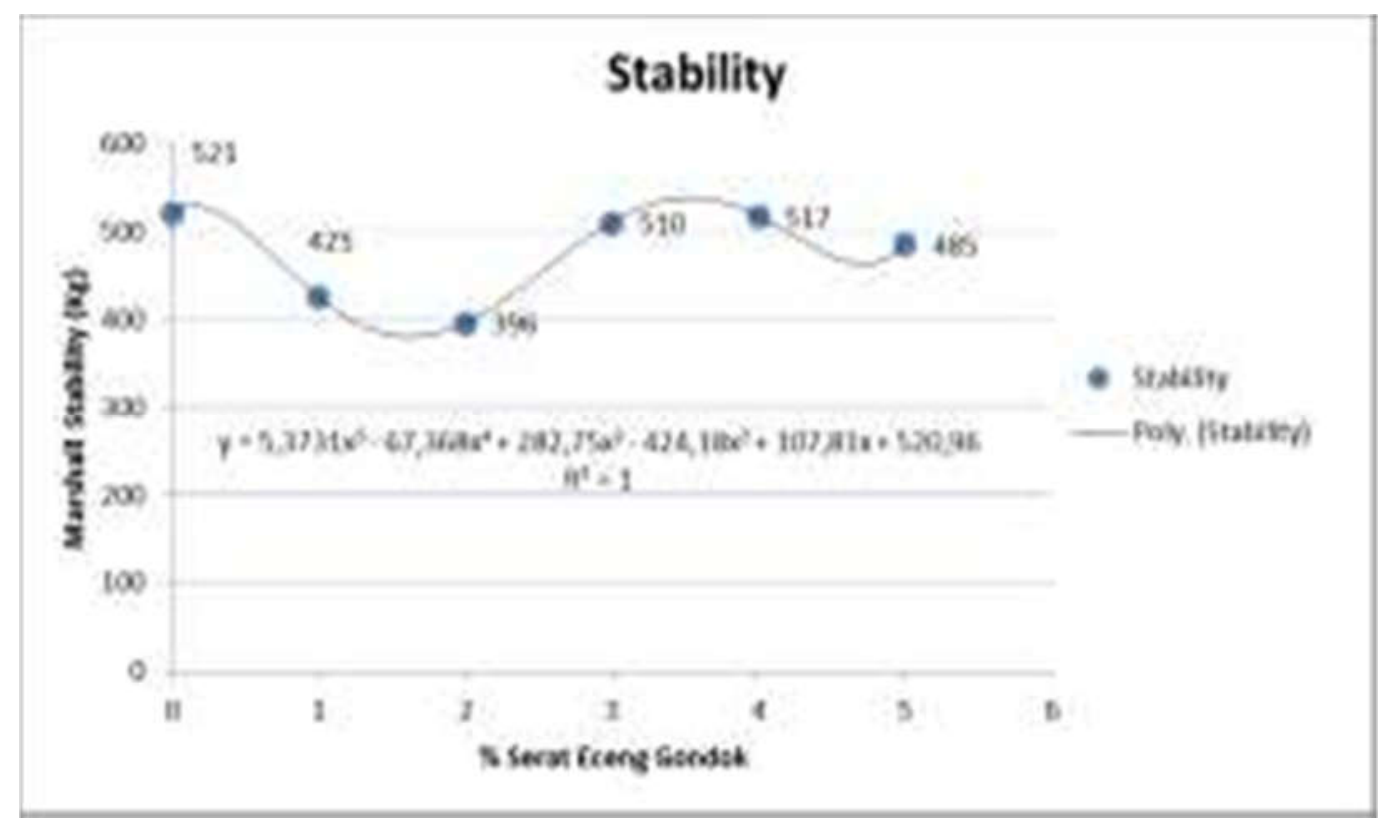


Gambar 1: Hubungan Marshall Stability Dengan Kadar Selulosa

Sumber : Hasil Penelitian, 2018

Dari gambar grafik hubungan stability marshall dengan kadar serat eceng gondok didapatkan nilai tertinggi pada penambahan kadar serat $3 \%$ dan $4 \%$.

\subsection{Rongga Dalam Campuran (Void In The Mix)}

Rongga udara dalam campuran (VIM) dalam campuran perkerasan beraspal terdiri atas ruang udara diantara partikel agregat yang terselimuti aspal.

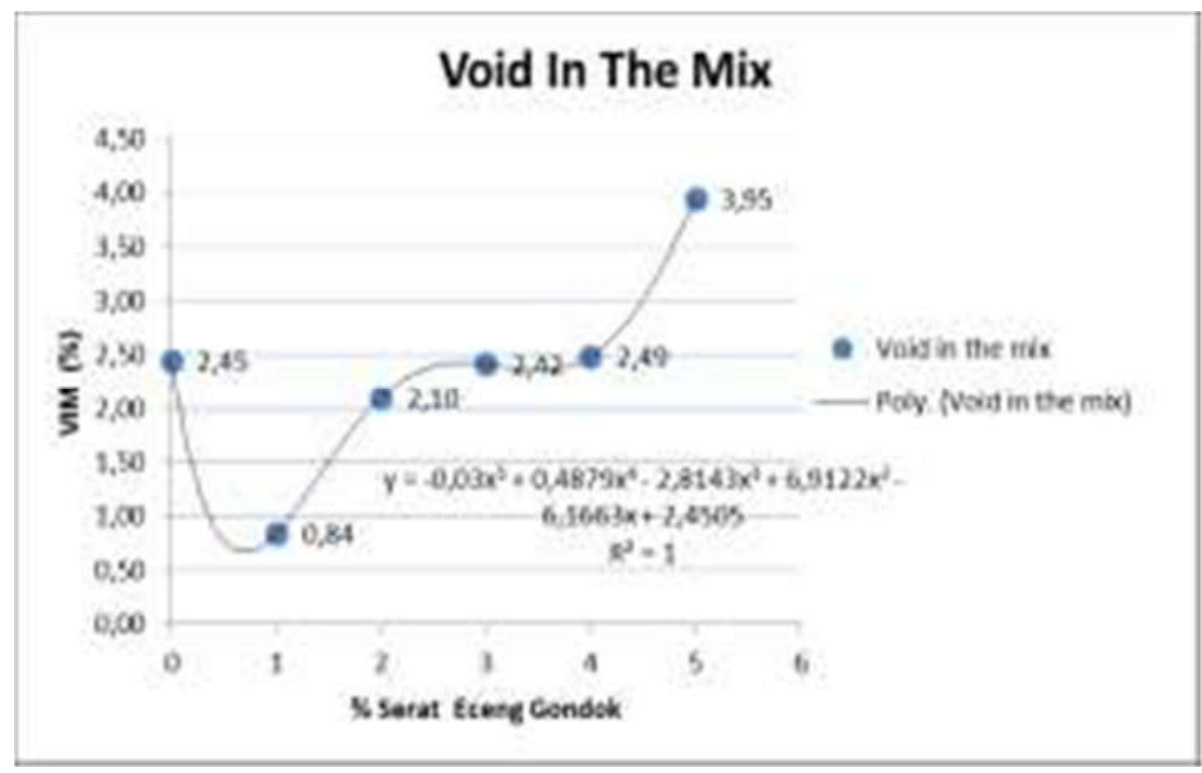

Gambar 2: Hubungan Void In The Mix Dengan Kadar Selulosa

Sumber : Hasil Penelitian, 2018

Dari gambar grafik hubungan Void In The Mix dengan kadar serat eceng gondok diatas didapatkan nilai tertinggi pada penambahan kadar serat $5 \%$.

\subsection{Rongga Dalam Mineral (Void In Mineral Aggregate)}

Rongga antar mineral agregat (VMA) adalah ruang rongga diantara partikel agregat pada suatu perkerasan, termasuk rongga udara dan volume aspal efektif (tidak termasuk volume aspal yang diserap agregat). 


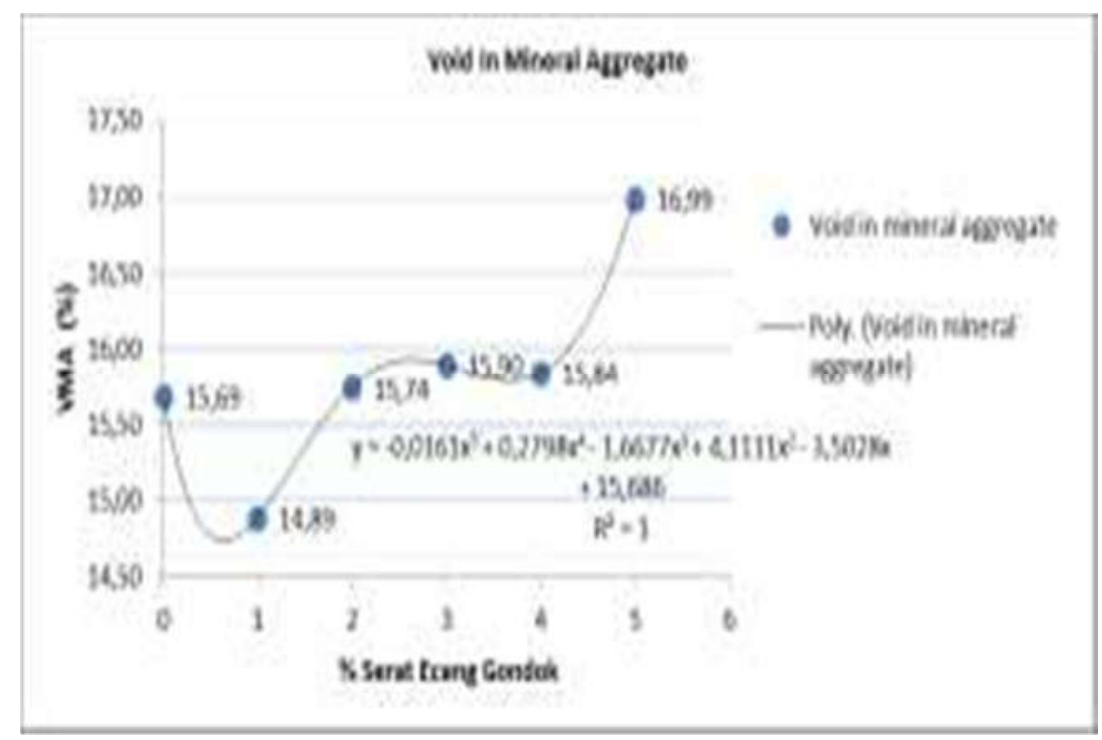

Gambar 3: Hubungan Void In Mineral Aggregate Dengan Kadar Selulosa

Sumber : Hasil Penelitian, 2018

Dari grafik hubungan Void In Mineral Agregate dengan kadar serat eceng gondok diatas didapatkan nilai tertinggi pada penambahan kadar serat $5 \%$

\subsection{Rongga Terisi Campuran Beraspal (Void Filled With Asphalt)}

Rongga terisi aspal atau Void Filled with Asphalt (VFWA) adalah persen rongga yang terdapat diantara partikel agregat (VMA) yang terisi oleh aspal, tidak termasuk aspal yang diserap oleh agregat.

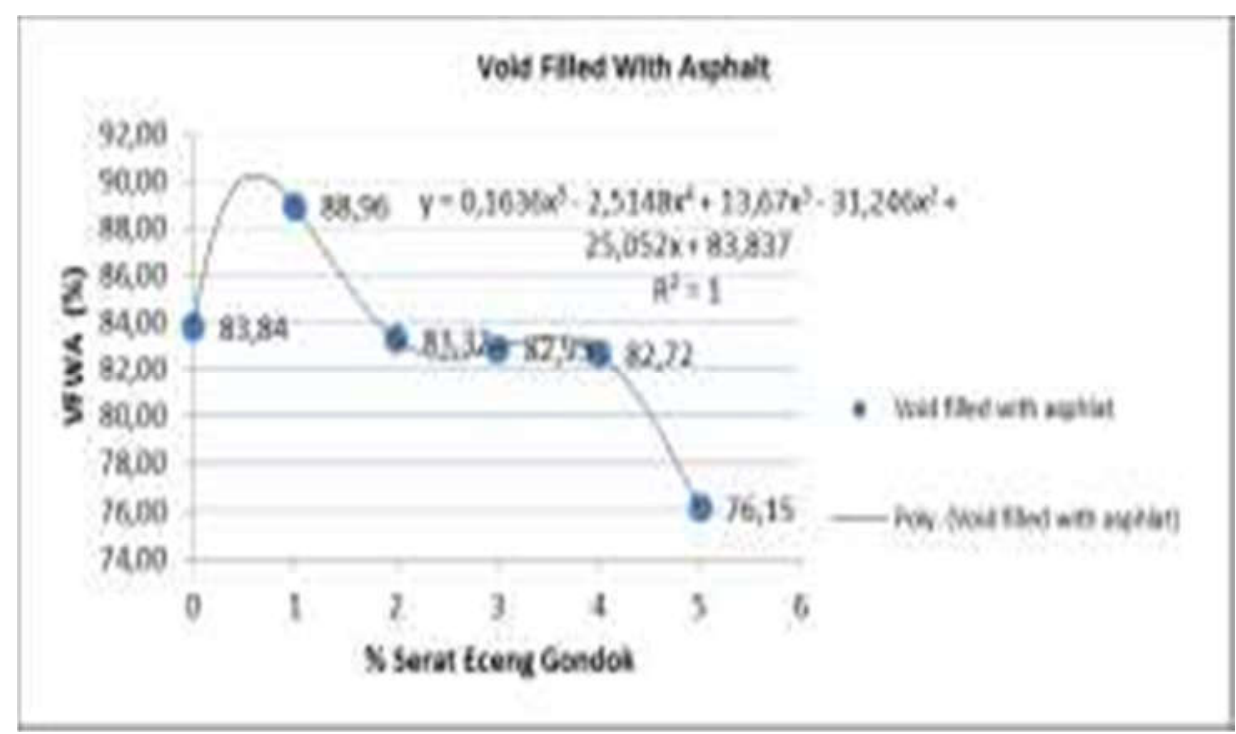

Gambar 4: Hubungan Void Filled With Asphalt Dengan Kadar Selulosa Sumber : Hasil Penelitian, 2018

Dari grafik hubungan Void Filled With Asphalt dengan kadar serat eceng gondok diatas didapatkan nilai tertinggi pada penambahan kadar serat $2 \%$

\subsection{Kelelehan (Flow)}


Nilai flow ditunjukkan oleh jarum arloji pembacaan flow pada alat Marshall. Untuk arloji pembacaan flow, nilai yang didapat sudah dalam satuan mm, sehingga tidak perlu dikonversi lebih lanjut.

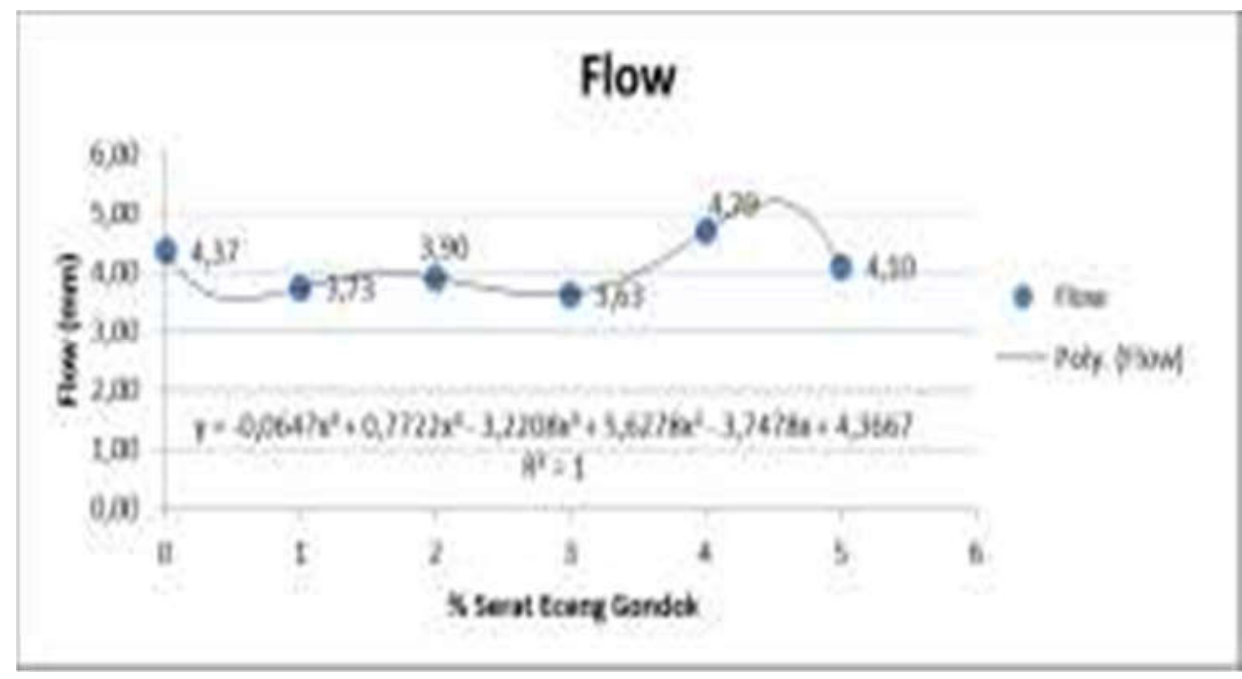

Gambar 5: Hubungan Flow Dengan Kadar Selulosa

Sumber : Hasil Penelitian, 2018

Dari grafik hubungan Void Filled With Asphalt dengan kadar serat eceng gondok diatas didapatkan nilai tertinggi pada penambahan kadar serat $4 \%$.

\subsection{Marshall Quotient}

Marshall Quotient adalah perbandingan antara nilai stabilitas dengan flow. Marshall Quotient merupakan indikator dalam menentukan nilai fleksibitas kelenturan terhadap keretakan. Kenaikan fleksibitas disebabkan oleh penambahan kadar aspal dan akan penurunan hingga batas optimum disebabkan oleh berubahnya fungsi aspal sebagai pengikat menjadi pelican.

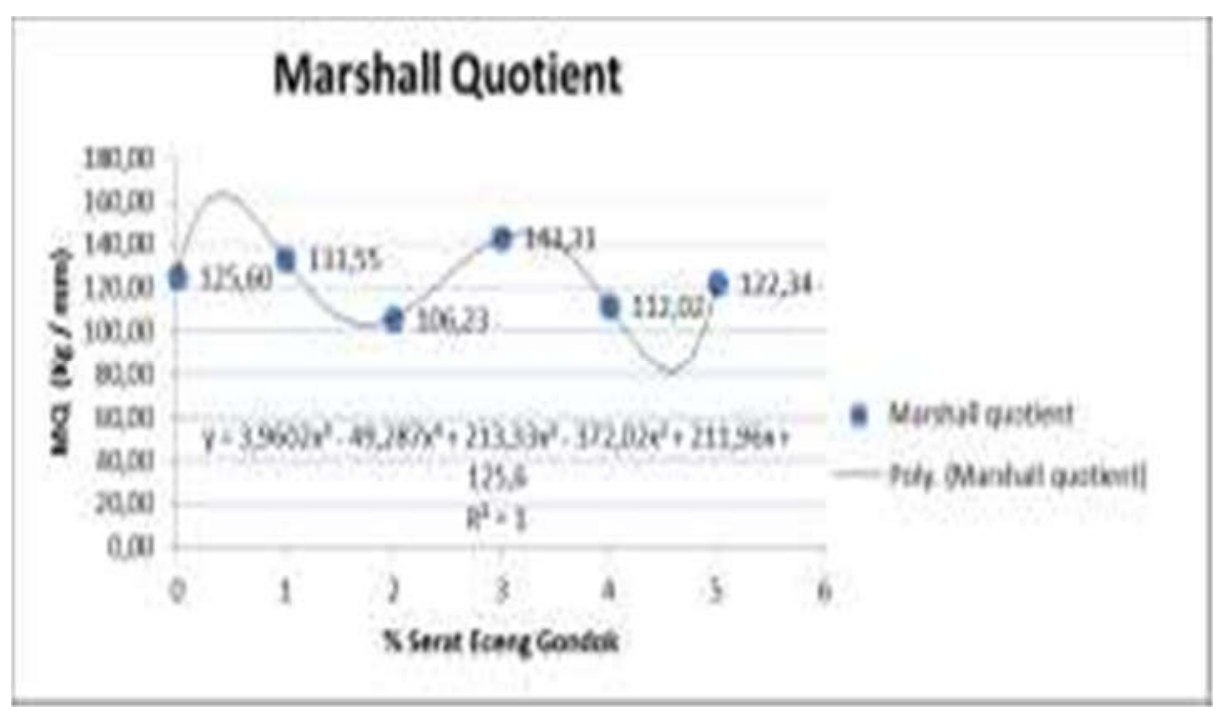

Gambar 6: Hubungan Marshall Quotient Dengan Kadar Selulosa

Sumber : Hasil Penelitian, 2018 


\section{KESIMPULAN}

a. Pada kondisi aspal optimum Marshall Stability mengalami penurunan dari 1\%, 2\%, 5\% dan meningkat dari 3\% - 4\% atan seiring bertambahnya prosentase kadarselulosa enceng gondok dalam dalam hal ini titik Marshall Stability terdapat pada variasi penambahan serat selulosa sebesar $3 \%$ dari berat aspal pada campuran dengan nilai Marshall Stability sebesar 55830,18 Kg. b. Pada kondisi aspal optimum persentase rongga dalam campuran (Void In The Mix) mengalami peningkatan cukup tinggi dari $1 \%-5 \%$ seiring dengan bertambahnya persentase kadar selulosa enceng gondok dalam campuran, dalam hal ini titik puncak VIM terdapat pada variasi penambahan serat selulosa sebesar $5 \%$ dari berat aspal pada campuran dengan nilai VIM sebesar $17,09 \%$.

c. Pada kondisi aspal optimum persentase rongga dalam campuran (Void In Mineral Aggregate) mengalami peningkatan dari $1 \%, 2 \%, 3 \%, 4 \%, 5 \%$, dengan seiring bertambahnya persentase kadar selulosa enceng gondok dalam campuran, hasil pemeriksaan menunjukkan bahwa titik puncak atau extreme point VMA terdapat pada variasi penambahan serat selulosa sebesar 5\% dari berat aspal pada campuran dengan nilai VMA sebesar $172,40 \%$.

d. Pada kondisi aspal optimum persentase rongga terisi aspal (Void Filled With Asphalt) mengalami penurunan cukup tajam dari 1\% - 5\% dengan seiring bertambahnya prosentase kadar selulosa dalam campuran, Dalam hal ini 6 titik puncak VFWA terdapat pada variasi penambahan serat selulosa sebesar $0 \%$ dari berat aspal pada campuran dengan nilai VFWA sebesar 2100,28 \%. e. Pada kondisi aspal optimum kelelahan plastis (flow) campuran mengalami penurunan dari $1 \%$, $2 \%, 3 \%, 5 \%$, dan yang mengalami kenaikan $4 \%$, seiring dengan bertambahnya persentase kadar selulosa enceng gondok dalam campuran, dalam hal ini titik Flow terdapat pada variasi penambahan serat selulosa sebesar 4,9\% dari berat aspal pada campuran dengan nilai Flow sebesar 2,23 $\mathrm{mm}$.

f. Pada kondisi aspal optimum ternyata Marshall Quotient (MQ) mengalami peningkatan dari 1\%, $3 \%, 5 \%$, dan mengalami penurunan dari $2 \%, 4 \%$, seiring bertambahnya persentase kadar selulosa dalam campuran, hasil pemeriksaan menunjukkan titik puncak atau extreme $\backslash$ point MQ terdapat pada variasi penambahan serat selulosa sebesar 3,1\% dari berat aspal pada campuran dengan nilai MQ sebesar 25984,39 Kg/mm.

Dari hasil keseluruan Marshaiil Test, di ketahui kadar penambahan eceng gondok $3 \%$ yang paling memenuhi di lihat dari stability, VIM, VMA, VFWA, Flow, dan MQ.

\section{DAFTAR PUSTAKA}

[1] AASHTO M 325., 2008, Standard Specification for Stone Matrix Asphalt (SMA). 
[2] AASHTO, 2008."Standard Specifications for Transportation Materials and Methods of Sampling and Testing, Part 2 : Tests." AASHTO, Washington D.C.

[3] Ahmad Bagir dan Gigih Eka Pradana., 2011.Pemanfaatan Serat Eceng Gondok

[4] Badan Standarisasi Nasional, 2012. SNI ASTM C136:2012 : Metode uji untuk analisis saringan agregat halus dan agregat kasar. Jakarta: BSN.

[5] Badan Standarisasi Nasional, SNI 8129:2015 tentang Spesifikasi Stone Matrix Asphalt (SMA)

[6] Badan Standarisasi Nasional, SNI 03-6388,2000, Spesifikasi Agregat Lapis Pondasi Bawah Lapis Pondasi Atas Dan Lapis Permukaan

[7] Badan Standardisasi Nasional. 2002. Spesifikasi Agregat Halus Untuk Campuran Perkerasan Beraspal, SNI 03-6819-2002. Jakarta

[8] Badan Standarisasi Nasiona,1 BSSNI, 2002. SKSNI 13-6717-2002. Tata Cara Penyiapan Benda Uji Dari Contoh Agregat

[9] Badan Standarisasi Nasional, BSSNI, 2011. SKSNI 2433-2011. Cara uji titik nyaladan titik bakar aspal dengan alat cleveland open cup

[10] Badan Standarisasi Nasional, BSSNI, 2011. SKSNI 2439-2011. Cara Uji Penyelimutan Dan Pengelupasan Pada Campuran Agregat-Aspal

[11] Badan Standarisasi Nasional, BSSNI, 2011. SKSNI 2456-2011. Tentang Cara Uji Penetrasi Aspal

[12] Badan Standarisasi Nasional, BSSNI,2011. SKSNI 2434-2011. Tentang Cara Uji Titik Lembek Aspal Dengan Alat Cincin Dan Bola (Ring And Ball)

[13] Badan Standarisasi Nasional' BSSNI, 2011. SKSNI 2441-2011. Tentang Cara Uji Berat Jenis Aspal Keras

[14] Direktorat Jendral Bina Marga., 2010. Spesifikasi Umum Direktorat Jenderal Bina Marga Edisi 2010 Divisi 6. Kementrian Pekerjaan Umum Indonesia.

[15] Lisminto dan As'ad M. 1993. Mekanisme Stabilisasi Aspal Oleh Serat Sellulosa di Dalam Campuran Splite Mastic Asphalt. Drektorat Jendral Bina

[16] Metode Pengujian Campuran Aspal dengan Alat Marshall, SNI 06-2489-1991. KementerianPekerjaan Umum, Badan Penelitian dan Pengembangan PU

[17] Sukirman Silvia (1999), Perkerasan Lentur JalanRaya, Nova,Bandung.

[18] Sukirman S., 2003. Beton Aspal Campuran Panas,Penerbit Granit, Jakarta 